\title{
Geodynamic and metabolic cycles in the Hadean
}

\author{
M. J. Russell and N. T. Arndt \\ Géosciences, LGGA, Université de Grenoble 1, 1381, rue de la Piscine, 38400 St. Martin d' Heres, France
}

Received: 26 July 2004 - Published in Biogeosciences Discussions: 22 September 2004

Revised: 1 February 2005 - Accepted: 28 February 2005 - Published: 5 April 2005

\begin{abstract}
High-degree melting of hot dry Hadean mantle at ocean ridges and plumes resulted in a crust about $30 \mathrm{~km}$ thick, overlain in places by extensive and thick mafic volcanic plateaus. Continental crust, by contrast, was relatively thin and mostly submarine. At constructive and destructive plate boundaries, and above the many mantle plumes, acidic hydrothermal springs at $\sim 400^{\circ} \mathrm{C}$ contributed $\mathrm{Fe}$ and other transition elements as well as $\mathrm{P}$ and $\mathrm{H}_{2}$ to the deep ocean made acidulous by dissolved $\mathrm{CO}_{2}$ and minor $\mathrm{HCl}$ derived from volcanoes. Away from ocean ridges, submarine hydrothermal fluids were cool $\left(\leq 100^{\circ} \mathrm{C}\right)$, alkaline $(\mathrm{pH} \sim 10)$, highly reduced and also $\mathrm{H}_{2}$-rich. Reaction of solvents in this fluid with those in ocean water was catalyzed in a hydrothermal mound, a natural self-restoring flow reactor and fractionation column developed above the alkaline spring. The mound consisted of brucite, Mg-rich clays, ephemeral carbonates, Fe-Ni sulfide and green rust. Acetate and glycine were the main products, some of which were eluted to the ocean. The rest, along with other organic byproducts were retained and concentrated within Fe-Ni sulfide compartments. These compartments, comprising the natural hydrothermal reactor, consisted partly of greigite $\left(\mathrm{Fe}_{5} \mathrm{NiS}_{8}\right)$. It was from reactions between organic modules confined within these inorganic compartments that the first prokaryotic organism evolved. These acetogenic precursors to the bacteria diversified and migrated down the mound and into the ocean floor to inaugurate the "deep biosphere". Once there they were protected from cataclysmic heating events caused by large meteoritic impacts. Geodynamic forces led to the eventual obduction of the deep biosphere into the photic zone where, initially protected by a thin veneer of sediment, the use of solar energy was mastered and photosynthesis emerged. The further evolution to oxygenic photosynthesis was effected as catalytic $[\mathrm{Mn}, \mathrm{Ca}]$-bearing molecules that otherwise would
\end{abstract}

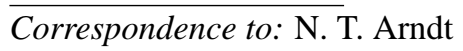

(arndt@ujf-grenoble.fr) have been interred in minerals such as ranciéite and hollandite in shallow marine manganiferous sediments, were sequestered and invaginated within the cyanobacterial precursor where, energized by light, they could oxidize water. Thus, a chemical sedimentary environment was required both for the emergence of chemosynthesis and of oxygenic photosynthesis, the two innovations that did most to change the nature of our planet.

\section{Introduction}

The Earth's internal thermal energy is mainly degraded through convection. Heat is transferred to the surface by a convecting mantle, to be discharged through volcanoes and hydrothermal springs into the ocean and atmosphere (the volatisphere). Chemical disequilibrium between reduced mantle and oxidized volatisphere is focused at springs and seepages on land or on the ocean floor. In turn this chemical energy is degraded through metabolism. Today metabolism relies on convection for supply of nutrients in the ocean, and on convection in the atmosphere for irrigation and chemical weathering of the land. The springs and seepages are oases of life in both realms.

At a broader scale and at slower rates, global geodynamic processes generate fresh, reduced rock surfaces that provide energy and supply nutrients to life. This coupling of metabolism to convection was directly implicated in the onset of life, which probably emerged at least 4 Gyr ago at moderate temperature seepages (Russell et al., 1988, 1994).

Reconstruction of the conditions that drove life to emerge and evolve its metabolic cycles is the main task of this paper. We begin by considering what present-day processes offer to the understanding of the conditions on the surface and in the interior of the Hadean/Archaean Earth, then suggest a scenario for the onset of life and its colonization of the ocean floor. This journey from geodynamics, through

(C) 2005 Author(s). This work is licensed under a Creative Commons License. 
Table 1. Examples of high- and moderate-temperature submarine springs.

\begin{tabular}{ccccc}
\hline Parameter & $\mathrm{J}^{\text {da Fuca }}{ }^{1}$ & Rainbow $^{2}$ & Lost City $^{3}$ & Eyjafjordur $^{4}$ \\
\hline $\mathrm{T}^{\circ} \mathrm{C}$ & $224^{\circ}$ & $365^{\circ}$ & $40^{\circ}-75^{\circ}$ & $71.4^{\circ}$ \\
$\mathrm{pH}$ & 3.2 & 2.8 & $\leq 9.8$ & $10.03\left(24^{\circ} \mathrm{C}\right)$ \\
duration yr & $>1000$ & $>1000$ & $>30000$ & 11000 \\
& & & & \\
$\mathrm{H}_{2} \mathrm{mmol}$ & na & 13 & 0.43 & na \\
$\mathrm{H}_{2} \mathrm{~S}$ & 3.5 & 1.0 & 0.064 & 0.01 \\
$\mathrm{SO}_{4}$ & 0 & $(0)$ & $5.9-12.9$ & 0.2 \\
$\mathrm{Fe}$ & 18.74 & 24 & na & 0.00014 \\
$\mathrm{Mn}$ & 3.58 & 2.25 & na & 0.0000018 \\
$\mathrm{Mg}$ & 0 & 0 & $9-19$ & 0.01 \\
$\mathrm{Ca}$ & 96.4 & 67 & 22 & 0.061 \\
$\mathrm{Na}$ & 796 & 553 & 482 & 3.4 \\
$\mathrm{~K}$ & 51.6 & 20 & na & 4.2 \\
$\mathrm{SiO}$ & 23.3 & 6.9 & na & 1.6 \\
$\mathrm{CO}$ & $\leq 4.46$ & na & na & 0.57 \\
$\mathrm{Cl}$ & 1087 & 380 & 548 & 1.26 \\
$\mathrm{Co}$ & na & 0.013 & na & na \\
$\mathrm{Ni}$ & na & 0.003 & na & na \\
$\mathrm{Zn}$ & 0.9 & 0.16 & na & na \\
$\mathrm{Mo}$ & na & 0.000002 & na & na \\
\hline
\end{tabular}

Data for column ${ }^{1}$. Von Damm (1990), ${ }^{2}$. Douville et al. (2002), ${ }^{3}$. Kelley et al. (2001) and Früh-Green et al. (2003), ${ }^{4}$. Marteinsson et al. (2001). Temperatures at the base of the convection cells developed at oceanic spreading centres and the off-ridge systems are presumed to be $\sim 400^{\circ} \mathrm{C}$ and $\sim 115^{\circ} \mathrm{C}$, respectively (Bischoff and Rosenbauer, 1984; Wenner and Taylor, 1971). The pH of the pristine alkaline fluid is also likely to have been $\sim 11$ (Neal and Stanger, 1983, 1984). The estimates of the duration of high-temperature discharge is taken from Elderfield and Schultz (1996). "na" signifies not analysed.

geochemistry to biochemistry leads us to conclude that obduction of oceanic crust facilitated the evolutionary jump to photosynthesis.

\section{The modern oceanic crust}

\subsection{Birth and death of oceanic crust}

A complete plate tectonic cycle starts with the formation of crust at a ridge and ends with its recycling to the mantle at a subduction zone. Continental crust forms above a subduction zone, a result of the melting of subducting oceanic crust and/or its dehydration, which triggers partial melting in the overlying mantle and the development of hydrous magmas. Superimposed on the plate tectonic cycle is the formation of oceanic islands and oceanic plateaus, which are generated by partial melting in mantle plumes.

\subsection{Modern hydrothermal systems - how they work}

Five main types of hydrothermal fluids circulate through modern oceanic crust: three high temperature types $\left(\leq 400^{\circ} \mathrm{C}\right)$ operate at oceanic ridges, above plumes and in back-arc basins respectively; an intermediate type occurs on ridge flanks $\left(\leq 115^{\circ} \mathrm{C}\right)$; and the last, far cooler, on the deep ocean floor (Anderson et al., 1977; Bonatti et al., 1983; Von Damm, 1990, Cathles, 1990; Sedwick et al., 1994; Kelley et al., 2001; Wheat et al., 2002; Früh-Green et al., 2003) (Table 1).

The temperature of the very hot springs, driven by magmatic intrusion, is controlled largely by the two-phase boundary of water and its critical point (Bischoff and Rosenbauer, 1984). Temperatures in modern hydrothermal convective systems, which bottom at an overall water column depth of $4 \mathrm{~km}$ or so, tend to peak at $\sim 400^{\circ} \mathrm{C}$. The fluids in the downdrafts become acidic $(\mathrm{pH} \sim 3)$ through the release of protons while $\mathrm{Mg}^{2+}$ is fixed in serpentine and brucite (Janecky and Seyfried, 1983; Douville et al., 2002). These acidic solutions dissolve, transport and exhale the transition metals, some phosphate, $\mathrm{H}_{2} \mathrm{~S}$ and $\mathrm{H}_{2}$, at black smokers (Table 1) (Von Damm, 1990; Kakegawa et al., 2002).

The temperatures and compositions of intermediatetemperature hydrothermal convection cells are controlled by exothermic reactions and the rheology of the newly serpentinized mafic-to-ultramafic wall rock of the conduits. So far the fluid from only one entirely submarine example of ultramafic interaction has been sampled, the "Lost City" field, $15 \mathrm{~km}$ from the Mid Atlantic Ridge (Kelley et al., 2001; Früh-Green et al., 2003). The $\mathrm{pH}$ of this water approaches 
10 as $\mathrm{Ca}(\mathrm{OH})_{2}, \mathrm{HCO}_{3}^{-}$and $\mathrm{H}_{2}$ are eluted, and the temperature is $70^{\circ}$ to $75^{\circ} \mathrm{C}$ (Table 1) (Kelley et al., 2001). Another broadly comparable system has been discovered in a fjord off the north coast of Iceland (Marteinsson et al., 2001; Geptner et al., 2002). Porous cones of Mg-rich clay (saponite), some tens of metres high, characterize this warm $\left(72^{\circ} \mathrm{C}\right)$ alkaline (pH 10), though fresh-water submarine spring (Table 1).

Still farther from ridges, even cooler circulation is driven by heat within the uppermost crust. Small closed convection cells are evenly spaced with a periodicity of about $7 \mathrm{~km}$, with thermal cusps around $20^{\circ} \mathrm{C}$ (Anderson et al., 1977).

\section{Hadean/Archaean ocean/atmosphere, oceanic crust and global dynamics}

\subsection{The volatisphere}

According to oxygen isotope analysis of the oldest known zircons, an ocean is assumed to have condensed on Earth by $4.4 \mathrm{Ga}$ (Wilde et al., 2001). The atmosphere contained $\mathrm{CO}_{2}$ and $\mathrm{N}_{2}$, some $\mathrm{HCl}, \mathrm{SO}_{2}, \mathrm{~S}^{0}$ and minor amounts of $\mathrm{H}_{2}$ and Ar (Kasting, 1993; Kasting and Brown, 1998; Pavlov and Kasting, 2002). Volcanogenic $\mathrm{CO}_{2}$ and $\mathrm{HCl}$, augmented by output from high temperature acid springs, rendered the early ocean acidulous ( $\mathrm{pH}$ 5-6) (Maisonneuve, 1982; Sedwick et al., 1994; Kasting, 1993; Macleod et al., 1994). The proportion of the $\mathrm{CO}_{2}$ depended on the balance between inputs from volcanic emissions and redissolution in the deep ocean and outputs via carbonation of the crust and of the dust thrown up by meteorite impacts (Alt and Teagle, 1999; Nisbet and Sleep, 2001). Transition metals and phosphate contributed by very hot springs remained in solution in this acidulous ocean (Kakegawa et al., 2002). Particularly important is $\mathrm{Fe}^{2+}$, some of which was photo-oxidized to insoluble flocs of $\mathrm{FeOOH}$ at the ocean's surface (Braterman et al., 1983; Gaffey, 1997; Russell and Hall, 2002).

\subsection{Crustal structure and composition}

Heat production in the Hadean was at least 5 times that of the present day and it is probable that the mantle was several hundred degrees hotter than it is today (Turcotte, 1980). Because the dehydration reactions that control the amount of water recycled to the mantle are temperature dependent, the Hadean mantle was drier than its modern counterpart. The ocean contained most of the Earth's water and its volume may have been up to twice that of today's oceans (Bounama et al., 2001). Upwelling of hot, dry mantle at oceanic spreading centres generated an early Archaean crust about $30 \mathrm{~km}$ thick (Sleep and Windley, 1982; Arndt and Chauvel, 1990) (Fig. 1). Oceanic plateaus, even more extensive than Ontong Java, covered large parts of the oceanic crust with an additional $30 \mathrm{~km}$ of mafic and ultramafic igneous rock. Both the oceanic crust and plateaus were internally differentiated. In each an upper $\sim 5 \mathrm{~km}$-thick layer of magnesian basalt overlay $\sim 10 \mathrm{~km}$ of gabbros and troctolites and $10 \mathrm{~km}$ or more of ultramafic cumulates (Francis et al., 1999; Foley et al., 2003).

The volume of continental crust in the early Archaean was a subject of intense debate in the 1980's. Geochemists tended to the interpretation that continental crust started to appear only around $3.8 \mathrm{Ga}$, the age of the oldest rocks known at that time. Since then several important discoveries have been made. The pre $4.2 \mathrm{Ga}$ zircons provide evidence for the existence of granitic rocks in the Hadean (Froude et al., 1983; Compston and Pidgeon, 1986) and their oxygen isotopic compositions suggest that an ocean had condensed on Earth by 4.4 Ga (Wilde et al., 2001; Mojzsis et al., 2001). Direct or indirect evidence for very old continental crust is becoming more abundant: the $4 \mathrm{Ga}$ Acasta gneisses (Bowring and Williams, 1999) contain 4.2 Ga zircons (Iizuka et al., 2002), and the recently discovered $3.8 \mathrm{Ga}$ Porpoise Cove supracrustal rocks on the east coast of Hudson Bay have Nd isotopic compositions indicating assimilation of still older granitoids (Stevenson et al., 2003). Although such an early age for the onset of subduction and the generation of granites is not without its critics (e.g. Glikson, 1972; Whitehouse and Kamber, 2002), ultra-high-pressure metamorphic rocks do indicate that portions of the continental crust are routinely cycled deep into the mantle. These discoveries provide mounting support for Armstrong's (1981, 1991) model of rapid early continental growth. In this model, granitic continental crust was abundant by the end of the Hadean.

The topography of the Hadean planet differed radically from that of the modern Earth. Because Hadean granitic crust contained higher concentrations of radioactive elements it was hotter, less viscous, and thinner than modern continental crust (Sandiford and McLaren, 2002). And because the mantle also was hotter, the continental lithosphere was thinner. Oceanic crust, in contrast, was much thicker than modern oceanic crust, as thick or thicker than the early Archaean continental crust. The oceans were more voluminous and they flooded a greater portion of the Earth's surface. Most of the continents were submerged and only mountain ranges at convergent margins and vast volcanic plateaus occasionally breached the ocean surface (Arndt, 1999) (Fig. 1). Thus there was little subaerial weathering and erosion of the mainly submerged continental masses and comparatively little clastic sedimentation.

Hydrated oceanic crust was continually cycled back into the mantle. At the base of the thickest sections, where oceanic plateaus had erupted onto the oceanic crust, pressures were sufficient to convert plagioclase to garnet. The downward drag of these dense eclogitised segments and the underlying dense Fe-rich ultramafic cumulates initiated subduction. Once started, the entire basaltic and gabbroic portion of the crust converted to eclogite, and plunged into the mantle (cf. Holmes, 1931). The earliest subduction zones probably were steeply dipping, rather than shallow, as is commonly assumed (Fig. 1) (Karsten et al., 1996). The upper layers of the crust dehydrated and triggered the melting in the 


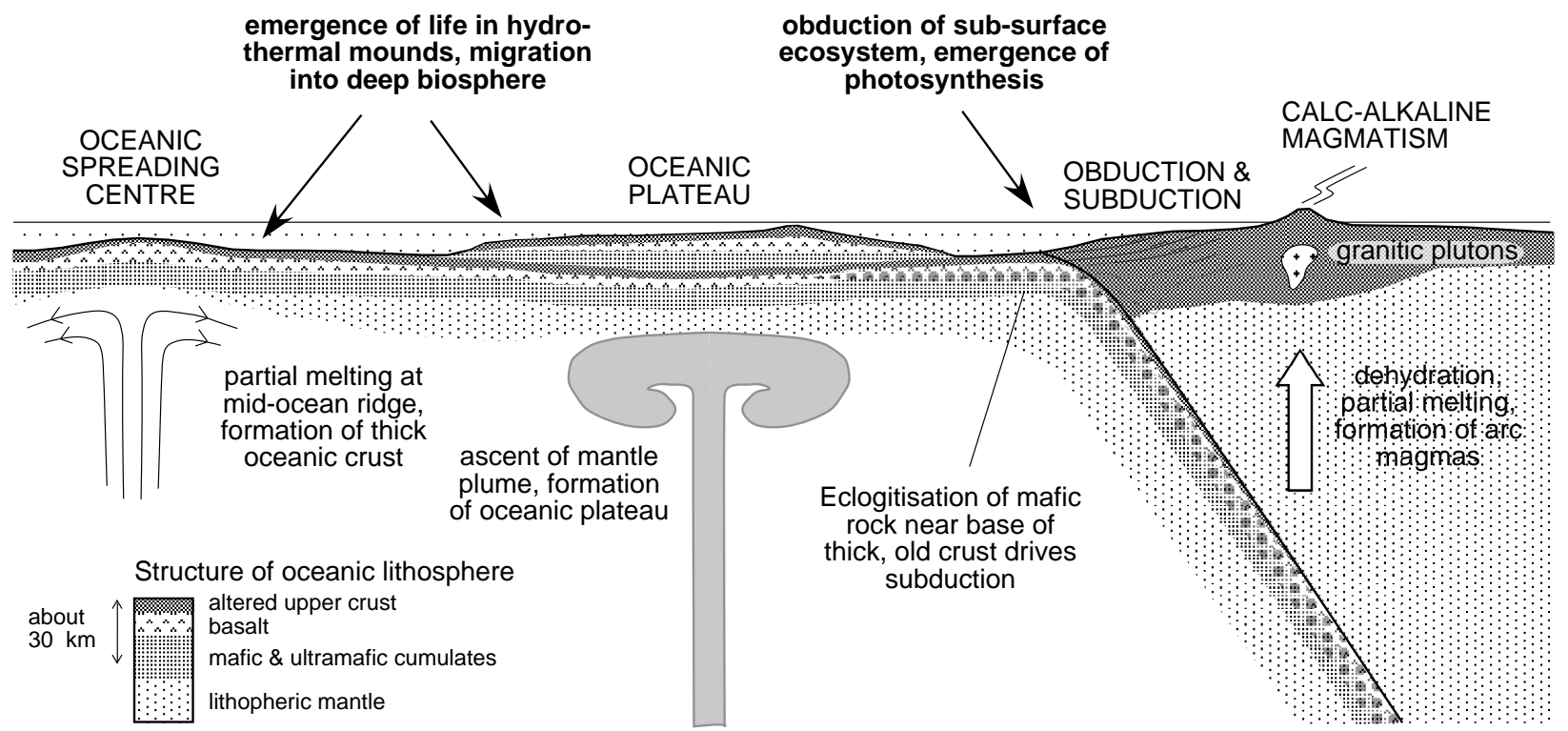

Fig. 1. Cross-section illustrating mantle convection on the Earth at the Hadean/Archaean boundary (Campbell et al., 1989; Davies, 1992; Foley et al., 2003; Fitton et al., 2004). Life is held to have emerged at an alkaline seepage site. An early batch of prokaryotic colonies was conveyed toward a plate margin where it was obducted into the photic zone, facilitating the onset of photosynthesis (Fig. 2). (At times and in places plume-type convective mass transfer may have involved the whole mantle).

over-riding mantle that gave rise to the magmas parental to continental crust. The uppermost parts of the oceanic crust obducted to form accretionary prisms of the type discussed by Maruyama (1997) and Foley et al. (2003). These prisms obliterated any nascent oceanic trenches, a process that was highly significant, as we shall see, to the development of photosynthesis.

\subsection{Hydrothermal circulation}

If we assume that the $400^{\circ} \mathrm{C}$ springs developed at constructive plate margins were comparable to those emanating from the ultramafic crust at the Rainbow field, the highly reduced acidic fluids would have carried about $20 \mathrm{mM}$ of $\mathrm{Fe}^{2+}$ to the ocean (Von Damm, 2000; Douville et al., 2002; Allen and Seyfried, 2003) (Table 1). With negligible marine sulfate in the Hadean (Farquar et al., 2000) there were no spontaneously precipitated protective anhydrite chimneys, and no black smokers. Hydrogen sulfide, reacting first with zinc, produced soluble but stable $\mathrm{ZnS}$ clusters as the solutions cooled on exhalation (Luther et al., 1999). Given the high remaining metal to sulfide ratio (Walker and Brimblecombe, 1985), much of the Fe and minor Ni stayed in solution in the acidulous ocean, though photo-oxidation of a proportion of the $\mathrm{Fe}^{2+}$ generated flocs of $\mathrm{FeOOH}$ (Braterman et al., 1983).

In marked contrast, the off-ridge springs would have had a similar temperature and chemistry to those of the present day $\left(\leq 100^{\circ} \mathrm{C}\right.$ and pH 9-11, Table 1) (Shock, 1992; Macleod et al., 1994; Kelley et al., 2001; Russell and Hall, 2002; Foley et al., 2003). Similar solutions may have exhaled from faulted zones within the oceanic plateaus. Such alkaline so- lutions could have provided $\sim 10 \mathrm{mM}$ of $\mathrm{HS}^{-}$to the seepage site (Macleod et al., 1994; Rahman, 2003). A mound of precipitates formed where these seepage waters met the acidulous ocean. The main precipitates were of brucite, iron and ephemeral calcium and magnesium carbonates, with subsidiary ferrous and ferric oxyhydroxides and iron $>$ nickel sulfides (Russell et al., 1988, 1998).

\subsection{Ocean temperatures}

The temperature of the Hadean ocean is uncertain. The effective radiative temperature of the Sun then was about $70 \%$ of its present output (Sagan and Mullen, 1972; Bahcall et al., 2001). Only the presence of atmospheric greenhouse gasses, $\mathrm{CO}_{2}$ or $\mathrm{CH}_{4}$, prevented the Earth from completely freezing over (Kasting, 1993). Indeed, temperatures may, on occasion, have approached $100^{\circ} \mathrm{C}$. But, as mentioned above, there were several effective sinks for $\mathrm{CO}_{2}$ including the extensive volcanic plateaus and the dust raised by meteorite impacts (Nisbet and Sleep, 2001). These impacts on the other hand may also have vaporized the ocean from time to time, though temperatures were never so high that a Venus-like atmosphere persisted, where $\mathrm{H}_{2}$ loss depleted the hydrosphere. Very likely there were frequent oscillations from hot (impact and green-house induced), to cold and partially frozen, a consequence of solar radiation masking by local or galactic dust clouds (Maher and Stevenson, 1988; Kasting, 1993, Kasting and Brown, 1998; Alt and Teagle, 1999; Nisbet and Sleep, 2001). Very cold conditions were short-lived because of continuous and widespread volcanicity and exhalations of $\mathrm{CO}_{2}$. Without the dampening capacity of large landmasses, con- 


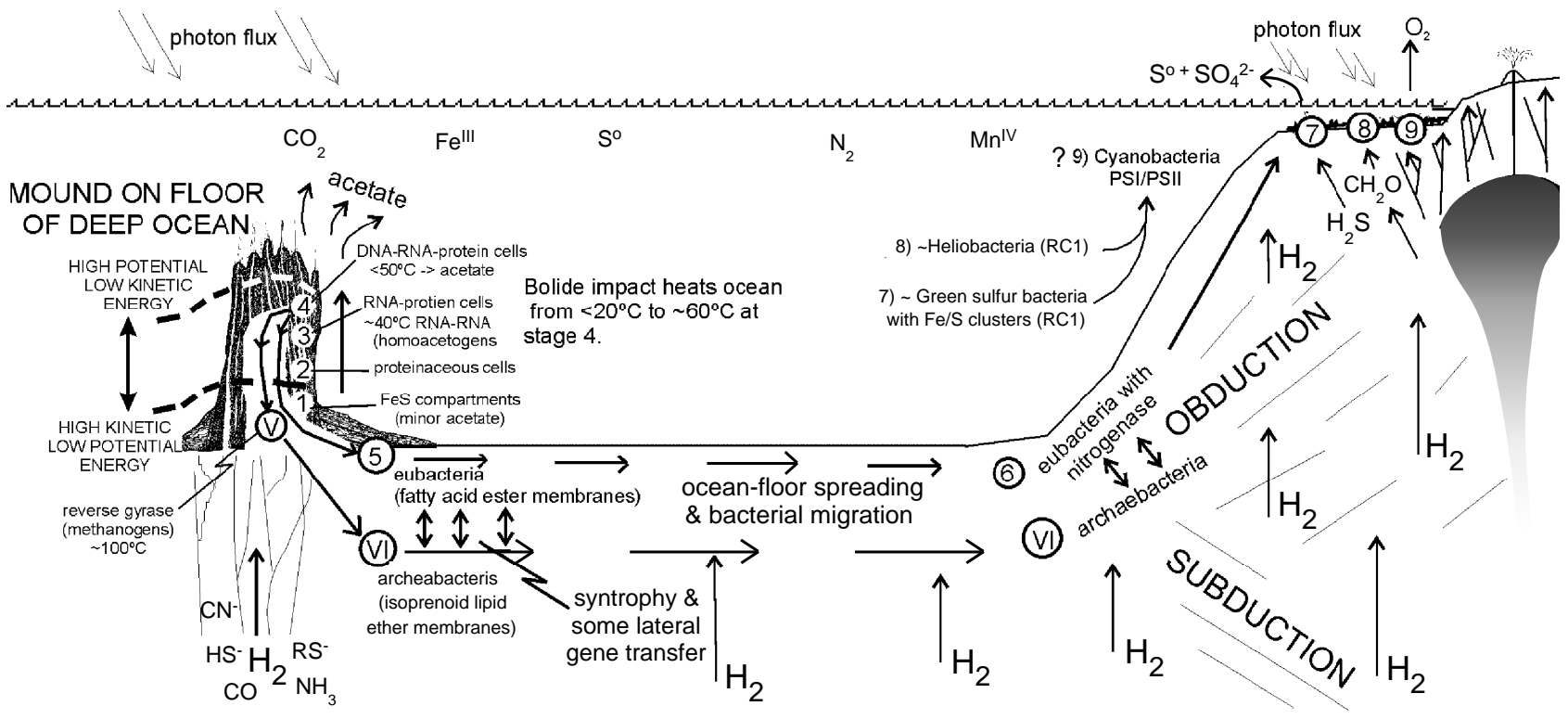

Fig. 2. Chemosynthetic life emerges at a warm alkaline seepage, differentiates into the precursors of the bacteria and archaea, and expands into the surrounding sediments and crust (Martin and Russell, 2003; Russell and Martin, 2004). From here a proportion is conveyed by ocean floor spreading toward a constructive margin produced partly by obduction. Once at the margin some of the cells happen to invade manganiferous sediments in the photic zone where, at a sulfurous spring, some evolve to exploit solar photons. Numbers 1-3 relate to life's emergence, 4 marks the point of differentiation of the archaea from the bacteria. Roman numerals V-VII mark evolutionary stages of the archaea, and 5 and 6 show stages of evolution of the bacteria in the deep biosphere. Photon energy may have been first mastered by the green sulfur bacteria (7), followed by the heliobacteria (8) (Vermaas, 1994; Baymann et al., 2001). These photosynthesizing bacteria had probable appeared by the early Archaean (Westall et al., 2001). Oxygenic photosynthesis (9) is a further evolutionary development, though the age of its emergence is highly controversial and its presence in this diagram is speculative (not to scale).

ditions at the ocean surface were likely to have been stormwracked whatever the temperature - too tempestuous for the collection of lipids and the focusing of energy and materials to convert them to cells with enzymes, metabolites and genomes.

Notwithstanding an earlier suggestion for a thermophilic start to life (Russell and Hall, 1997), because of the fragility of RNA, and because the acetogenic pathway operates best below about $50^{\circ} \mathrm{C}$, we recognise that life is unlikely to have emerged at temperatures much above $40^{\circ} \mathrm{C}$ (Forterre, 1996; Schink, 1997; Moulton et al., 2000; Brochier and Philippe, 2002). And because a thermal gradient is required to drive convection, we suggest that life's emergence had to await a period, or "window of opportunity" when oceanic temperatures were low, perhaps around $20^{\circ} \mathrm{C}$ (but see Schwartzman and Lineweaver, 2004, for a contrary view). However, once life had emerged it had to survive the Hadean periods of high temperature. How this was done will have to be addressed in our hypothesis of life's emergence and early evolution.

\section{Chemical contribution to the onset of life}

\subsection{The hydrothermal mound}

Haeckel (1892, p. 414) considered life to have emerged from an "inorganic formative fluid", and Leduc (1911, p. xv) sug- gested that "the chain of life is ... a continuous one, from the mineral at one end to the most complicated organism at the other". In Leduc's view the first compartments to store the potential energy that drove life to emerge were also inorganic. These prescient ideas were ignored, partly because they seemed to hark back to theories of spontaneous generation put paid to famously by Pasteur, and partly because scientists were loath to consider anything but an organic origin for any organic being. The organic view has held sway for 75 years (Bada, 2004). However, the inorganic hypothesis has since been disinterred and we suggest that a stable, long-lived alkaline submarine seepage of moderate temperature satisfies Haeckel's expectations (Russell et al., 1988, 2003). Further, we suggest that Leduc's inorganic compartments may have comprised catalytic iron(nickel) sulfides generated at this same seepage (Russell et al., 1994). This idea is given further significance by the recognition that iron and sulfur comprise the active centres to a protein with the longest pedigree, the electron transfer agent known as ferredoxin - a metabolic enzyme which is strongly electronegative with a potential close to that of molecular hydrogen (Eck and Dayhoff, 1966; Hall et al., 1971).

Portions of a hydrothermal mound comprising freshly precipitated films of iron sulfide in the form of disordered nanometric mackinawite $\left(\mathrm{Fe}_{1+x} \mathrm{~S}\right)$ and minor greigite $\left(\mathrm{Fe}_{5} \mathrm{NiS}_{8}\right)$ offered semipermeable and semiconducting containers for 
both organic synthesis and retainment (Russell and Hall, 1997; Filtness et al., 2003; Wolthers et al., 2003). Strong gradients developed at the outer margins of such a mound where the reduced alkaline hydrothermal solution interfaced the cooler, more oxidized Hadean ocean. Potentials focused across the iron sulfide membranes were hydrodynamic (between buoyant hydrothermal solution and ocean), thermal $\left(<20^{\circ}\right.$ to $115^{\circ} \mathrm{C}$ ), chemical (between hydrothermal $\mathrm{H}_{2}$ and $\mathrm{CO}_{2}$ ) and electrochemical (between redox couples $\mathrm{H}^{+} / \mathrm{H}_{2}$ and $\mathrm{Fe}^{3+} / \mathrm{Fe}^{2+}$ ) (Russell and Martin, 2004). Electrons could also be gained from $\mathrm{H}_{2} \mathrm{~S}_{\text {and }} \mathrm{HS}^{-}$.

Reduction of $\mathrm{CO}_{2}$ or $\mathrm{HCO}_{3}^{-}$to $\mathrm{CO}$ with activated $\mathrm{H}_{2}$ (as $\mathrm{H} \cdot$ ) is assumed to take place on nanocrystals of mackinawite and greigite (Russell et al., 1998; Russell and Martin, 2004). Further reduction to methane thiol $\left(\mathrm{CH}_{3} \mathrm{~S}^{-}\right)$, involving $\mathrm{H} \cdot$ is activated hydrogen, i.e. a highly reactive hydrogen atom and $\mathrm{HS}^{-}$, is strongly thermodynamically favoured (Schulte and Rogers, 2004). Heinen and Lauwers (1996) have produced methane thiol directly by reduction of $\mathrm{CO}_{2}$ with the concomitant oxidation of $\mathrm{FeS}$ to pyrite by $\mathrm{H}_{2} \mathrm{~S}$, as might be expected of the "pyrite-pulled" hypothesis of Wächtershäuser (1988). Huber and Wächtershäuser (1997) have reacted CO and $\mathrm{CH}_{3} \mathrm{SH}$ to produce acetate $\left(\mathrm{H}_{3} \mathrm{C} . \mathrm{COO}^{-}\right)$in yields of $40 \%$ with respect to the thiol. Experimental conditions were $100^{\circ} \mathrm{C}$ at a $\mathrm{pH}$ of 6.4 . These chemical and physical states can be met near the surface of the hydrothermal mound. It appears then that the first result of a reaction between an alkaline hydrothermal fluid and carbonic ocean water will be acetate. Indeed, acetate is the product of what is known as the acetyl coenzyme-A pathway - the most ancient of the metabolic pathways (Peretó et al., 1999; Russell and Martin, 2004).

In their experiments Huber and Wächtershäuser (1997) used a slurry of iron sulfide and nickel sulfide. However, Russell et al. (1998) pointed out that greigite and violarite $\left(\mathrm{Fe}_{2} \mathrm{Ni}_{4} \mathrm{~S}_{8}\right)$ are more likely to have been the catalysts. The high acetate yields are an expression of the thermodynamic calculations of Shock et al. (1998), who demonstrated the reaction between $\mathrm{CO}_{2}$ and $\mathrm{H}_{2}$ with the production of acetate to be extremely favourable (exergonic). The structure of greigite $\left(\mathrm{Fe}_{5} \mathrm{NiS}_{8}\right)$ is strikingly similar to the active centres (e.g. $\mathrm{Fe}_{4} \mathrm{NiS}_{5}$ ) of the enzymes presently involved in the reduction of $\mathrm{CO}_{2}$ and the formation of acetate (Vaughan and Craig, 1978; Russell et al., 1994, 1998; Russell and Martin, 2004). These enzymes are known as carbon monoxide dehydrogenase/acetyl co-enzyme-A synthase (CODH/ACS) (Dobbeck et al., 2001; Drennan et al., 2001; Darnault et al., 2003). The same enzymes are known to have the facility to activate $\mathrm{H}_{2}$ (Menon and Ragsdale, 2000).

We can say then that the first microbe used the energy and materials within the hydrothermal solution and the ocean to generate acetate and water as waste products, i.e. it was an "acetogen" (Russell and Martin, 2004). The emergence of life and the generation of acetate waste within the natural hydrothermal reactor can be considered rather as we might characterize mineral precipitation at a hot spring, though as soon as organic molecules are formed in the process they have the effect of inhibiting mineral growth (e.g. Rickard et al., 2001). Indeed, we can think of the active centres of the metalloproteins as "still-born" mineral clusters. The approximate and highly simplified formula for "proto-life" used here $\left[\mathrm{C}_{70} \mathrm{H}_{129} \mathrm{O}_{65} \mathrm{~N}_{10} \mathrm{P}(\mathrm{Fe}, \mathrm{Ni}, \mathrm{Co}, \mathrm{Zn}, \mathrm{Mo}) \mathrm{S}\right]$ is gleaned from a number of sources (Redfield et al., 1963; Orr, 1978; Morel and Hudson, 1985; Faggerbakke et al., 1996; Macalady and Banfield, 2003). The trace metal contents are rather exaggerated in keeping with their likely contribution to the first living cells. The reactions that generated this proto-life and waste can be put notionally as:

$$
\begin{aligned}
& \left\{407 \mathrm{H}_{2}+10 \mathrm{NH}_{3}+\mathrm{HS}^{-}\right\}^{\text {hydrothermal }} \\
& +\left\{210 \mathrm{CO}_{2}+\mathrm{H}_{2} \mathrm{PO}_{4}^{-}+\mathrm{Fe}, \mathrm{Ni}, \mathrm{Co}, \mathrm{Zn}^{2+}\right\}^{\text {ocean }} \rightarrow \\
& \left\{\mathrm{C}_{70} \mathrm{H}_{129} \mathrm{O}_{65} \mathrm{~N}_{10} \mathrm{P}(\mathrm{Fe}, \mathrm{Ni}, \mathrm{Co}, \mathrm{Zn}) \mathrm{S}\right\}^{\text {protolife }} \\
& +\left\{70 \mathrm{H}_{3} \mathrm{C} . \mathrm{COOH}+219 \mathrm{H}_{2} \mathrm{O}\right\}^{\text {waste }} .
\end{aligned}
$$

Note the high waste-to-protolife molecular ratio.

In this explanation the hydrothermal mound is viewed as a self-restoring catalytic flow reactor that synthesized acetate (Russell and Martin, 2004). More complex organic molecules were minor by-products of the reaction, by-products that were to optimize acetate production. Of particular significance was the amino acetic acid glycine $\left({ }^{+} \mathrm{H}_{3} \mathrm{~N} \cdot \mathrm{CH}_{2} \cdot \mathrm{COO}^{-}\right)$, produced in hydrothermal experiments by Hennet et al. (1992). Once glycine appeared in the sulfide compartments, the redox and $\mathrm{pH}$ gradients came into effect (Russell and Hall, 1997, 2002). The alkaline mounds constituted the hydrogen electrode, or cathode, and the photolytic ferric iron flocculants (denoted by $\mathrm{Fe}^{\mathrm{III}}$ ) aggregated at the mound's exterior, acted as a positive electrode. The $\mathrm{Fe}^{\mathrm{III}} / \mathrm{Fe}^{3+}$ provides a fraction of the potential, augmented by the exterior protons, that results in polymerization (Russell and Hall, 1997, 2002). Fe $\mathrm{I}^{\mathrm{III}}$ accepted the electrons ultimately contributed by hydrothermal $\mathrm{H}_{2}$. Most prokaryotes near the root of the evolutionary tree can use $\mathrm{Fe}^{\mathrm{III}}$ as an electron acceptor, supporting the notion that it was the first to fulfill this vital role (McFadden and Shively, 1991; Liu et al., 1997; Pace, 1997; Russell and Hall, 1997; Vargas et al., 1998; Reysenbach and Lovley, 2002).

Today we recognize the power of light to directly drive much metabolism. In the Hadean the photolytic Fe $\mathrm{F}^{\mathrm{III}}$ represented a "borrowed light" that energized and helped drive life's emergence (Cairns-Smith et al., 1992; Russell and Hall, 2002). In theory, the electrochemical potential approaches one volt (Russell and Hall, 1997; Russell et al., 1998); in practice, Russell and Hall (2002) and Filtness et al. (2003) have demonstrated that an FeS membrane, spontaneously precipitated at the interface between solutions containing $10 \mathrm{mM}$ of $\mathrm{Fe}^{2+}$ on the one side, and $10 \mathrm{mM} \mathrm{HS}{ }^{-}$ on the other, can hold a tension of 600 to $700 \mathrm{mV}$ for several hours. The gradients have the potential to drive the polymerization of inorganic phosphate if water activity 
were low (Baltscheffsky, 1996). Polymerization may have taken place on the surfaces of closely packed mackinawite or greigite nanoclusters making up the inorganic membrane (cf. Huber and Wächtershäuser, 1998, 2003; de Zwart et al., 2004). In turn, and on the same surfaces, the pyrophosphate might have polymerized the glycine to form homopeptides. Alternatively, local generation of $\mathrm{CO}$ or COS upon sulfide could have driven polymerization (Huber and Wächtershäuser, 1998; Huber et al., 2003; Leman et al., 2004).

Once primitive peptides formed they will have coordinated the building blocks of greigite (e.g. $\left[\mathrm{Fe}_{2} \mathrm{~S}_{2}\right]^{+},\left[\mathrm{Fe}_{4} \mathrm{~S}_{4}\right]^{2+}$ and perhaps $\left[\mathrm{Fe}_{4} \mathrm{~S}_{6} \mathrm{Ni}\right]^{+}$) that had been inhibited from further growth by organic sulfides such as ethane thiol $\left(\mathrm{CH}_{3} \mathrm{CH}_{2} \mathrm{~S}^{-}\right)$ (Bonomi et al., 1985; Stevens and Kurtz, 1985). This was the beginning of the organic take-over from a mineral based prebiotic chemistry (Milner-White and Russell, 2005). These peptides may have contributed to a mixed polymer membrane, more stable and flexible than its inorganic precursor, yet with sequestered sulfides and phosphate, still able to gain electrochemical energy and nutrients from outside the individual cells (cf. Cole et al., 1994).

\subsection{Evolution in the mound}

Newly evolved acetogens were the forerunners of the bacteria. However, evolution in the mound extended beyond mere optimization of the chemotrophic acetate reaction (Martin and Russell, 2003). The next step was the adaptation to organotrophy, the digestion of the reduced carbon and energy to be found in dead cells. A minority of cells, derived from those that emerged at around $40^{\circ} \mathrm{C}$, exploited the potential offered at higher temperature elsewhere in the mound where the kinetic energy was greater and the activation energy required for reduction, through acetate, all the way to methane, was lower. That the first "methanogens" may have evolved while still in the mound, is argued because there is even more energy to be had in the full reduction of $\mathrm{CO}_{2}$ (Amend and Shock, 2001). Moreover, the metalloenzymetic machinery required for acetogenesis and methanogenesis is similar, though the structures of the organic carbon/nitrogen catalysts are rather different (Fontecilla-Camps and Ragsdale, 1999; Thauer, 1998). Moreover, methanogenic archaea can derive energy by generating methane from the acetate waste from neighbouring acetogens (Madigan et al., 2000):

$$
\mathrm{CH}_{3} \cdot \mathrm{COO}^{-}+\mathrm{H}_{2} \mathrm{O} \rightarrow \mathrm{CH}_{4}+\mathrm{HCO}_{3}^{-} \text {. }
$$

Russell and Hall (2002) suggested that such methanogenic cells were the precursors of the archaea, the sturdy but slowly evolving second domain of the prokaryotes (Woese et al., 1990). If so, the last common ancestor of life occupied the very hatchery in which life first emerged, and the most significant of all cellular differentiations, that between the bacteria and the archaea, probably took place before the mound was evacuated (Koga et al., 1998; Martin and Russell, 2003). Up till this time of divergence, genes were shared like software packages in what may be called a cellular cooperative. Eventually there was a differentiation of cells as opportunities for exploratory evolution and specialization in this previously empty habitat presented themselves, a differentiation partly driven by entropy - random changes in genes that eventually gave mutually exclusive phenotypes (Wicken, 1987). By this stage $\mathrm{Mn}^{\mathrm{IV}}$ and $\mathrm{S}^{0}$ had joined $\mathrm{Fe}^{\mathrm{III}}$ and $\mathrm{CO}_{2}$ as electron sinks.

In summary we can say that bacteria were initially suited to low to moderate temperatures, and the archaea originally evolved from them to withstand relatively high temperatures (i.e. $\sim 55^{\circ} \mathrm{C}$ ). But the propensity to live well above $40^{\circ} \mathrm{C}$ was passed back to the nascent bacteria through genetic transfer. A period of high ambient temperature, caused either by an impacting large meteorite or a $\mathrm{CO}_{2}$ greenhouse (Kasting and Akerman, 1986; Kasting and Brown, 1998; Nisbet and Sleep, 2001) could explain why the last common ancestor of all life may have been a thermophile, perhaps living at $50^{\circ}$ to $60^{\circ} \mathrm{C}$ (Gaucher et al., 2003). Whatever the heating event, it was from the surviving community that the evolutionary tree was seeded.

Representatives of, and in, both domains found it advantageous to live syntrophically. Cells would have relied upon their neighbours to swap genes, provide some of the nutrients and to remove some of the waste (e.g. Eq. 2) (Morita, 2000). Unfortunates that were entrained within the hydrothermal solution and dispersed to the ocean could not have survived such dilution of nutrient or ocean-evaporating impact events (Sleep et al., 1989; Bjerrum and Canfield, 2002). The only way out was down - down onto the ocean floor and into the warm chemical sediments and permeable basalts below.

\subsection{Inauguration of the deep biosphere}

Growth and expansion of the colonies of acetogens and methanogens followed the redox front laterally out of the mound and into the surrounding sediments. Colonization of the entire seafloor and upper crust was relatively rapid as microbial colonies were entrained in aqueous advection currents. $\mathrm{H}_{2}$ continued to be the available fuel, diffusing into the sediments and volcanic rocks from hydrating crust and mantle (Apps and van der Kamp, 1993). $\mathrm{H}_{2}$ was also provided by some of the fellow metabolizing cells within the syntrophic communities (Wolin, 1982; Towe, 1996). $\mathrm{CO}_{2}$ for biosynthesis continued to be available in downward percolating ocean water. And photolytic $\mathrm{Fe}^{\mathrm{III}}$, already deposited on the ocean floor, would have continued to act as a terminal electron acceptor so that electrochemical potential was maintained. At some stage fatty acids and lipids would have started to space out and replace much of the protein in the membrane (Martin and Russell, 2003).

Once life had emerged and gained a foothold in the sediments and hydrated volcanics of the ocean bottom it would have been extremely hard to eradicate. Strong Earth 
tides resulting from the shorter day and lunar cycle and the closer moon continuously pumped the required nutrients from above and below through fractures in the upper crust (Davis and Becker, 1999). Only Fe ${ }^{\mathrm{III}}$, the main electron acceptor in the chemical sediments, may have been in short supply. Even so, a small flux of $\mathrm{H}_{2}$ was enough to prevent the decay of cellular material and the racemization of peptides (Morita, 2000).

Thus the deep biosphere was born (Parkes et al., 1990, 1994; Pedersen, 1993; Thorseth et al., 1995; Wellsbury et al., 1997; Whitman et al., 1998; Kotelnikova and Pedersen, 1997; Furnes et al., 2004). At this depth, as the thermal conductivity of saturated sediment and basalt is so low, the prokaryotes were well protected by a layer of insulating sediment and basalt from the thermal effects of impacts, even of those that may have caused the entire ocean to volatilize (Sleep et al., 1989).

\section{Obduction and the emergence of photosynthesis}

Given that conditions for life in the open sea were most inhospitable, how do we explain the emergence of photosynthetic organisms in the full glare of hard UV from the young sun (Canuto et al., 1982)? We suggest that obduction brought microbial consortia from the deep ocean floor into the photic zone. Because of the particular geometry of Hadean oceanic crust, chemical sediment overlying hydrated basaltic crust was obducted over the subducting, delaminated, eclogitised lower parts of the slab. Obduction of oceanic sediments, particularly of hydrated iron and manganese oxyhydroxides precipitated on the margins of volcanic chains, and of the hydrated basalt beneath, passively transported some bacterial colonies into shallow water and into the photic zone. Cells were protected from deleterious solar radiation beneath a mineral coating, perhaps within a biofilm (Cockell and Knowland, 1999). Opportunistic protection by superposed minerals and mineral excretions are well-known prokaryotic protective gambits (Phoenix et al., 2001). And the absorption and accumulation of manganese is also likely to have conferred resistance to radiation (Daly et al., 2004). In these conditions some bacteria near the surface further augmented their resistance to solar radiation by developing a UV pigment protector from a ring of organic bases. Pigments comprising macrocyclic aromatic rings probably date back to at least $4 \mathrm{Ga}$ (Pratt, 1993). Single ions of $\mathrm{Fe}, \mathrm{Mg}, \mathrm{Co}, \mathrm{Ni}, \mathrm{Cu}$ and $\mathrm{Zn}$ can be sequestered individually in variants of what is known as the corrin or tetrapyrrole ring, itself comprising four C/N rings (Pratt, 1993; Eschenmoser, 1998; Allen, 2005). Pigments developed for photoprotection could then have been adapted as electron transfer agents, as photosynthetic reaction centres and antenna proteins (Mulkidjanian et al., 1997; Allen, 2005).

\subsection{The first photosynthesists}

The process of photosynthesis was mastered at least by the early Archaean (Westall et al., 2001). The first photosynthesizing bacterium may have been a precursor to the green sulfur bacteria (Baymann et al., 2001). Like some prephotosynthetic bacteria, these bacteria relied lithotrophically on $\mathrm{H}_{2} \mathrm{~S}$ as an electron donor. Just as in modern island arcs and accretionary prisms, hydrothermal $\mathrm{H}_{2} \mathrm{~S}$ of magmatic or metasomatic derivation would have circulated through the sediments in the obducted pile (Fig. 2). In these conditions, a photosynthetic reaction centre ( $\mathrm{RC} 1$ ) could have developed that catalysed the generation of elemental sulfur and water as waste, and gained electrons and protons in the process (Eq. 3).

$2 \mathrm{H}_{2} \mathrm{~S}+\mathrm{CO}_{2}+$ light $\rightarrow\left(\mathrm{CH}_{2} \mathrm{O}\right)^{\text {life }}+\mathrm{H}_{2} \mathrm{O}+2 \mathrm{~S}^{0}$.

As we might expect of gradualistic evolution, the green sulfur bacteria continued to rely on iron sulfide clusters as electron transfer agents (Blankenship, 2002).

An evolutionary variant - a photosynthetic precursor of the heliobacteria bacteria - was able to fix $\mathrm{CO}_{2}$ with electrons supplied indirectly by organic detritus (Vermaas, 1994). This change of electron source echoes the early evolution of biosynthesis, beginning with lithotrophs, followed by rapid and opportunistic adaptation to organotrophy (Sect. 4.2). The heliobacteria substituted a pigment as an electron transfer agent in place of some of the iron-sulfur centres (Allen, 2005). But they retained the use of photosynthetic reaction centre 1 (RC1) (Dismukes et al., 2001; Blankenship, 2002).

\subsection{Oxygenic photosynthesis}

The photosystem (PS2) employed by all cyanobacteria and plants to oxidize water only required gene duplication and gene splitting to descend from RC2 (Baymann et al., 2001). These genes could have been gained from green sulfur bacteria and/or heliobacteria (Michel and Deisenhofer, 1988; Baymann et al., 2001). In a variant of the hypothesis, Allen (2005) has argued that photosystem 1 (PS1) and PS2 diverged from reaction centres within a common anaerobic ancestor, perhaps a green filamentous bacterium. PS2 works in conjunction with PS1, itself also probably evolved from the first reaction centre (RC1) (Baymann et al., 2001). PS2 is capable of oxidizing two molecules of $\mathrm{H}_{2} \mathrm{O}$ (cf. the one molecule of $\mathrm{H}_{2} \mathrm{~S}$ in the green sulfur bacteria shown in Eq. 3) during the generation of a single molecule of $\mathrm{O}_{2}$, gaining incrementally in the process four electrons and four protons for the fixation of carbon from $\mathrm{CO}_{2}$ or $\mathrm{HCO}_{3}^{-}$for biosynthesis (Hansson and Wyddrzynski, 1990) (Eqs. 4 and 5).

$$
\begin{aligned}
& 2 \mathrm{H}_{2} \mathrm{O}+\text { light } \rightarrow 4 \mathrm{H}^{+}+4 \mathrm{e}^{-}+\mathrm{O}_{2} \\
& 2 \mathrm{CH}_{2} \mathrm{O}+2 \mathrm{CO}_{2}+\text { light } \rightarrow\left(2 \mathrm{H}_{2} \mathrm{O}\right)^{\text {life }}+2 \mathrm{O}_{2} .
\end{aligned}
$$

PS2 oxidizes water using what is known as the oxygenevolving centre (OEC). Its active site comprises a $\mathrm{CaMn}_{4}$ 
centre (Dismukes, 200). At this site the electrons and protons are stripped from the bonded water in the OEC and transferred separately to engender biosynthesis, while the two remaining oxide ions bond covalently to form waste $\mathrm{O}_{2}$. To explain such an extraordinary innovation Russell and Hall (2002) suggested that a small cluster, which otherwise would have been interred in the phyllomanganate mineral ranciéite $\left[\mathrm{CaMn}_{4}^{4+} \mathrm{O}_{9} \cdot 3 \mathrm{H}_{2} \mathrm{O}\right]$, was co-opted on the outer surface of the membrane of the photosynthetic precursor, and from there sequestered into a protein complex as a "ready-made" catalytic centre. Such phyllomanganates (e.g. the birnessites) are produced by hard UV radiation $(\lambda \sim 225 \mathrm{~nm})$ from $\mathrm{Mn}^{2+}$. bearing waters (Anbar and Holland, 1992). They occur widely today in seafloor $\mathrm{Mn} / \mathrm{Fe}$ nodules as well as in submarine exhalites (Burns and Burns, 1979). In ranciéite the $\mathrm{Ca}^{2+}$ (or a diadochic reduced $\mathrm{Mn}^{2+}$ ) is coordinated with three oxygens as well as to the oxygens of three water molecules (cf. Post and Veblen, 1990; Manceau et al., 2002). However, Ferreira et al. (2004) have now shown that the OEC comprises a cubane containing one $\mathrm{Ca}$ atom and three $\mathrm{Mn}$ ions. This $\mathrm{CaMn}_{3} \mathrm{O}_{4}$ cubane is coordinated to a peripheral Mn (Ferreira et al., 2004). Yet the two water molecules are bound between the calcium and the distal manganese. Despite the similar stoichiometry, as the structure of ranciéite does not involve a cubane it could not have been a direct precursor. More in keeping with the Ferreira model are entities of the hollandite $\left[\left(\mathrm{Ba}, \mathrm{Mn}^{2+}\right) \mathrm{Mn}_{7}^{4+} \mathrm{O}_{16}\right]$ structure favoured by Sauer and Yachandra (2004). Such manganese minerals do readily participate in redox reactions (Sunda et al., 1983; Post, 1999).

In the light of this information, we now imagine the precursors to the cyanobacteria embedded at the top of shallow-water, photolytically precipitated, sedimentary manganese oxides. These precipitates, aptly named umbers when found in more recent oceanic crust (Constantinou and Govett, 1972), not only provided some shade to these precursors, but also contributed the facility to oxidize water, i.e., a "catalase" activity. Here the cyanobacteria precursors exploited the protons and electrons released to them from $\left[\mathrm{CaMn}_{4}\right]$ structures by photons, to reduce bicarbonate ions in pore spaces (Dismukes et al., 2001; Russell et al., 2003). Eventually these $\left[\mathrm{CaMn}_{4}\right]$ molecules with photolytic function were invaginated to become a primitive oxygen evolving complex (OEV). Alternatively, because the adventitious accumulation of $\mathrm{Mn}^{\mathrm{II}}$ inside a bacterium afforded strong protection from hard UV and therefore survival, once there it could, along with $\mathrm{Ca}^{2+}$, have formed a cubane and been chelated by an aspartate- and glutamate-bearing protein. Placed within the membrane, it exerted a water-oxidizing capability. Deinococcus radiodurans is known to be tolerant to high doses of gamma-radiation, a tolerance imparted by the accumulation of manganese (Daly et al., 2004). Whatever the details, it does seem likely that this extraordinary innovation, like the emergence of chemosynthetic life itself, also required chemical sediment for protection, support and as a source of metal ions.

\subsection{The appearance of oxygenic photosynthesis}

We do not know when oxygenic photosynthesis started. Did it appear in the Hadean or at the end of the Archaean, over a billion years later? Geochemical evidence from the Isua Banded Iron Formation (Dymek and Klein, 1988), from radio- and stable isotopes in rocks of the same age (Rosing and Frei, 2003), and 16sRNA evolutionary trees (Pace, 2002), have been taken to imply that it emerged before 3.75 $\mathrm{Ga}$. But soil profiles lacking $\mathrm{Fe}^{\mathrm{III}}$ and the absence in rocks of the petrified polysaccharide-rich sheaths around fossil cells to be expected of cyanobacteria seem to point to a late or post Archaean age (Westall 2001, 2003, 2004). Indeed, Blank (2004) suggests that oxygenic photosynthesis did not emerge until immediately prior to the Great Oxidation Event at ca. $2.3 \mathrm{Ga}$ (Holland, 2002).

In the absence of further discriminatory evidence our own preference - based on our plate tectonic scenario, the similarity of the oxygen-evolving centre to a hollandite cluster, the rapidity in which dynamic structures evolve and emerge in the Universe, the pedigree of PS2 founded in the antecedent $\mathrm{RC} 2$, and the likely concentrations of phyllomanganates, as well as of manganese ions in pore waters of littoral sediments - is for the early onset of oxygenic photosynthesis. The absence of atmospheric oxygen prior to $2.3 \mathrm{Ga}$ would then be explained by the flooding of the atmosphere with methane and hydrogen from the deep biosphere, by the buffering effects of reduced iron and sulfide in the ocean and crust, the relatively low productivity in the oceans, and by the reduction of $\mathrm{O}_{2}$ by ambient bacteria in microbial mats (Lécuyer and Ricard, 1999; Farquar et al., 2000; Hoehler et al., 2001; Catling et al., 2001; Timmins et al., 2001; Bjerrum and Canfield, 2002; Arnold et al., 2004).

\section{Conclusions}

1. Geodynamic and metabolic cycles are closely coupled on our planet, a coupling that would have been even more direct at the onset of life when hydrothermal output from an alkaline submarine seepage of moderate temperature was the input to the first metabolizing systems (Russell and Martin 2004). These "metabolists" developed within catalytic iron sulfide compartments in the hydrothermal mound, gained genetic machinery and thereby evolved while still within the mound. There they differentiated into the two prokaryotic domains, the bacteria and the archaea (Martin and Russell, 2003). It is likely that life had emerged on the planet at least by 4.2 Ga (Russell and Hall, 1997).

2. Gradual expansion of colonies of prokaryotes from the mound into the surrounding sediments on the ocean floor guaranteed a similar protected environment, though nutrient was at a premium, a factor encouraging both syntrophic cooperation and evolution. From here 
the colonies were entrained in migrating fluids to depth in the oceanic crust to inaugurate the deep biosphere (Parkes et al., 1990, 1994; Pedersen, 1993; Thorseth et al., 1995). A continual draft of $\mathrm{H}_{2}$ from the crust and mantle prevented bacterial decay even in periodic absences of an electron acceptor and bicarbonate and other feedstock (Morita, 2000).

3. Because of the relatively low conductivity of mafic rock, the deep biosphere could remain out of reach of meteorite-induced heating events.

4. Obduction of the deep biosphere into the photic zone allowed evolution within shallow water chemical sediments, first of photoprotective molecules developed from aromatic ring compounds previously employed in group and electron transfer, and from these to photosynthetic reaction centres and antenna proteins (Mulkidjanian et al., 1997; Baymann et al., 2001; Allen, 2005).

5. The first photosynthesists, probably precursors of the green sulfur bacteria, used hydrothermal $\mathrm{H}_{2} \mathrm{~S}$ as an electron donor and produced $\mathrm{S}^{0}$ and water as waste. The next, perhaps precursors of the heliobacteria, used organic waste as the ultimate electron donor (Vermaas, 1994). The biggest evolutionary leap followed, and either involved the heterodimerization of the reaction centres of the green sulfur bacteria and the heliobacteria (Bayman et al., 2001), or the divergence of PS1 and PS2 from reaction centres within a green filamentous bacterium (Allen, 2005). Either way a combined cyanobacterial PS1 and PS2 was the result (Blankenship, 2002). This system could oxidize $\mathrm{H}_{2} \mathrm{O}$ leaving $\mathrm{O}_{2}$ as waste (Dismukes et al., 2001). In doing so, protons and electrons were entrained and used in biosynthesis.

6. Both chemosynthesis and oxygenic photosynthesis emerged within the confines of mineral constituents (iron sulfides and manganese oxides respectively) with catalytic propensity. Molecules that otherwise would have been contributed to the growth of sulfide and oxide minerals were sequestered into the first acetogens and the first oxygen evolving photosynthetic bacteria respectively. Co-opted as vital catalysts, as reactive centres, these transitional metal complexes are employed in the same roles in protein complexes to this day.

Acknowledgements. This paper was written while MJR was a visiting professor at University Joseph Fourier in Grenoble. The research was supported by grants to NTA from two programmes of the Centre National de Recherche Scientifique: the Programme Nationale de Planétologie and the Groupement de Recherche d'Exobiologie. We thank W. Nitschke, B. Martin and A. Hall for their help, and L. Charlet, W. Nitschke, and F. Westall for reviews of the manuscript.

Edited by: F. Westall

\section{References}

Allen, D. A. and Seyfried, W. E.: Compositional controls on vent fluids from ultramafic - hosted hydrothermal systems at mid-ocean ridges: An experimental study at $400^{\circ} \mathrm{C}, 500$ bars, Geochimica et Cosmochimica Acta, 67, 1531-1542, 2003.

Allen, J. F.: A redox switch hypthesis for the origin of two light reactions in photosynthesis, FEBS Letters, 579, 963-968, 2005.

Alt, J. C. and Teagle, D. A. H.: The uptake of carbon during alteration of the oceanic crust. Geochimica et Cosmochimica Acta, 63, 1527-1535, 1999.

Amend, J. P. and Shock, E. L.: Energetics of overall metabolic reactions of thermophilic and hyperthermophilic Archaea and Bacteria, FEMS Microbiological Reviews, 25, 175-243, 2001.

Anbar, A. D. and Holland, H. D.: The photochemistry of manganese and the origin of banded iron formations, Geochimica et Cosmochimica Acta, 56, 2595-2603, 1992.

Anderson, R. B., Langseth, M. G., and Sclater, J. G.: The mechanisms of heat transfer through the floor of the Indian Ocean, J. Geophys. Res., 82, 3391-3409, 1977.

Apps, J. A. and Van der Kamp, P. C.; Energy gases of abiogenic origin in the Earth's crust, The future of energy gases, US Geological Survey Professional Paper 1570, 81-132, 1993.

Armstrong, R. L.: Radiogenic isotopes: the case for crustal recycling on a near-steady-state no-continental-growth Earth, Philosophical Transactions of the Royal Society of London (Ser. A), 301, 443-472, 1981.

Armstrong, R. L.: The persistent myth of crustal growth, Australian Journal of Earth Sciences, 38, 613-630, 1991.

Arnold, G. L., Anbar, A. D., Barling, J., and Lyons, T. W.: Molybdenum isotope evidence for widespread anoxia in MidProterozoic oceans, Science, 304, 87-90, 2004.

Arndt, N. T.: Why was flood volcanism on submerged continental platforms so common in the Precambrian?, Precambrian Research, 97, 155-164, 1999.

Arndt, N. T. and Chauvel, C.: Crust of the Hadean Earth, Bulletin Geological Society of Denmark, 39, 145-151, 1990.

Bada, J. L.: How life began on Earth: a status report, Earth Planet. Sc. Lett., 226, 1-15, 2004.

Bahcall, J. N., Pinsonneault, M. H., and Basu, S.: Solar models: Current epoch and time dependences, neutrinos, and helioseismological properties, Astrophys. J., 555, 990-1012, 2001.

Baltscheffsky, H.: Energy conversion leading to the origin and early evolution of life: Did inorganic pyrophosphate precede adenosine triphosphate? In Origin and Evolution of Biological Energy Conversion, edited by: Baltscheffsky, H., VCH Publishers, Cambridge, 1-9, 1996.

Baymann, F., Brugna, M., Mühlenhoff, U., and Nitschke, W.: Daddy, where did (PS)I come from?, Biochimica Biophysica Acta, 1507, 291-310, 2001.

Baymann, F., Lebrun, E., Brugna, M., Schoepp-Cothenet, B., Giudici-Orticoni, M. T., and Nitschke, W.: The redox protein construction kit: pre-last universal common ancestor evolution of energy-conserving enzymes, Philosophical Transactions of the Royal Society of London, 358B, 267-274, 2003.

Bekker, A., Holland, H. D., Wang, P.-L., Stein, H. J., Hannah, J. L., Coetzee, L. L., and Beukes, N. J.: Dating the rise of atmospheric oxygen, Nature, 427, 117-120, 2004.

Bischoff, J. L. and Rosenbauer, R. J.: The critical point and twophase boundary of seawater, $200-500^{\circ} \mathrm{C}$, Earth Planet. Sc. Lett., 
68, 172-180, 1984.

Bjerrum, C. J. and Canfield, D. E.: Ocean productivity before about 1.9 Gyr ago limited by phosphorus adsorption onto iron oxides, Nature, 417, 159-162, 2002.

Blank, C. E.: Evolutionary timing of the origins of mesophilic sulphate reduction and oxygenic photosynthesis: a phylogenomic dating approach, Geobiology, 2, 1-20, 2004.

Blankenship, R. E.: Molecular Mechanisms of Photosynthesis, Blackwell Science, Oxford, 2002.

Bonatti, E., Simmons, E. C., Breger, D., Hamlyn, P. R., and Lawrence, J.: Ultramafic rock/seawater interaction in the oceanic crust: $\mathrm{Mg}$-silicate (sepiolite) deposit from the Indian Ocean floor, Earth Planet. Sc. Lett., 62, 229-238, 1983.

Bonomi, F., Werth, M. T., and Kurtz, D. M.: Assembly of $\mathrm{Fe}_{n} \mathrm{~S}_{n}(\mathrm{SR})^{2-}(n=2,4)$ in aqueous media from iron salts, thiols and sulfur, sulfide, thiosulfide plus rhodonase, Inorg. Chem., 24, 4331-4335, 1985.

Bounama, C., Franck, S., and von Bloh, W.: The fate of the Earth's ocean, Hydrol. Earth Sys. Sci., 5, 569-575, 2001,

SRef-ID: 1607-7938/hess/2001-5-569.

Bowring, S. A. and Williams, I. S.: Priscoan (4.00-4.03 Ga) orthogneisses from northwest Canada, Contributions Mineralogy Petrology, 134, 3-16, 1999.

Boyle, J. F.: The composition and origin of oxide metalliferous sediments from the Troodos ophiolite, Cyprus, in Ophiolilites, Oceanic Crustal Analogues, edited by: Malpas, J., Moores, E. M., Panayiotou, A., and Xenophontos, C., Cyprus Geological Survey Department, Nicosia, 705-717, 1990.

Braterman, P. S., Cairns-Smith, A. G., and Sloper, R. A.: Photooxidation of hydrated $\mathrm{Fe}^{2+}$ - significance for banded iron formations, Nature, 303, 163-164, 1983.

Brochier, C. and Philippe, H.: A non-hyperthermophilic ancestor for bacteria, Nature, 417, 244, 2002.

Cairns-Smith, A. G., Hall, A. J., and Russell, M. J.: Mineral theories of the origin of life and an iron sulphide example, Origins of life and evolution of the Biosphere, 22, 161-180, 1992.

Campbell, I. H., Griffiths, R. W., and Hill, R. I.: Melting in an Archaean mantle plume: heads it's basalts, tails it's komatiites, Nature, 339, 697-699, 1989.

Canfield, D. E. and Raiswell, R.: The evolution of sulfur cycles, American Journal of Science, 299, 697-723, 1999.

Canuto, V. M., Levine, J. S., Augustsson, T. R., and Imhoff, C. L.: UV radiation from the young Sun and oxygen and ozone levels in the prebiological palaeoatmosphere, Nature, 296, 816820, 1982.

Cathles, L. M.: Scales and effects of fluid flow in the upper crust, Science, 248, 323-329, 1990.

Catling, D. C., Zahnle, K. J., and McKay, C. P.: Biogenic methane, hydrogen escape, and the irreversible oxidation of early Earth, Science, 293, 839-843, 2001.

Cockell, C. S. and Knowland, J.: UV radiation screening compounds, Biological Reviews, 74, 311-345, 1999.

Cole, W. J., Kaschke, M., Sherringham, J. A., Curry, G. B., Turner, D., and Russell, M. J.: Can amino acids be synthesised by $\mathrm{H}_{2} \mathrm{~S}$ in anoxic lakes?, Marine Chemistry, 45, 243-256, 1994.

Compston, W. and Pidgeon, R. T.: Jack Hills, evidence of more very old detrital zircons in Western Australia, Nature, 321, 766-769, 1986.

Constantinou, G. and Govett, G. J. S.: Genesis of sulphide deposits, ochre and umber of Cyprus, Institution of Mining and Metallurgy, Transactions, 8, B36-B46, 1972.

Daly, M. J., Gaidamakova, E. K., Matrosova, V. Y., Vasilenko, A., Zhai, M., Venkateswaran, A., Hess, M., Omelchenko, M. V., Kostandarithes, H. M., Makarova, K. S., Wackett, L. P., Fredrickson, J. K., and Ghosal1, D.: Accumulation of Mn(II) in Deinococcus radiodurans facilitates gamma-radiation resistance, Science, 306, 1025-1028, 2004.

Darnault, C., Volbeda, A., Kim, E. J. Legrand, P., Vernède, X., Lindahl, P. A., and Fontecilla-Camps, J. C.: Ni-Zn- $\left[\mathrm{Fe}_{4}-\mathrm{S}_{4}\right]$ and Ni$\mathrm{Ni}-\left[\mathrm{Fe}_{4}-\mathrm{S}_{4}\right]$ clusters in closed and open $\alpha$ subunits of acetyl-CoA synthase/carbon monoxide dehydrogenase, Nature Structural Biology, 10, 271-279, 2003.

Davies, G. F.: On the emergence of plate tectonics, Geology, 20, 963-966, 1992.

Davis, E. E. and Becker, K.: Tidal pumping of fluids from the oceanic crust: New observations and opportunities for sampling the crustal hydrosphere, Earth Planet. Sc. Lett., 172, 141-149, 1999.

de Zwart, I. I., Meade, S. J., and Pratt, A. J.: Biomimetic phosphoryl transfer catalysed by iron(II)-mineral precipitates, Geochimica et Cosmochimica Acta, 68, 4093-4098, 2005.

Dismukes, G. C., Klimov, V. V., Baranov, S. V., Kozlov, Yu. N., DasGupta, J., and Tyryshkin, A.: The origin of atmospheric oxygen on Earth: The innovation of oxygenic photosynthesis, Proceedings of the National Academy of Science, USA, 99, 2170 2175, 2001.

Dobbeck, H., Svetlitchnyi, V., Gremer, L., Huber, R., and Meyer, O.: Crystal structure of a carbon monoxide dehydrogenase reveals a [Ni-4Fe-5S] cluster, Science, 293, 1281-1285, 2001.

Douville, E., Charlou, J. L., Oelkers, E. H., Bienvenu, P., Colon, C. F. J., Donval, J. P., Fouquet, Y., Prieur, D., and Appriou, P.: The rainbow vent fluids $\left(36^{\circ} 14^{\prime} \mathrm{N}, \mathrm{MAR}\right)$ : the influence of ultramafic rocks and phase separation on trace metal content in MidAtlantic Ridge hydrothermal fluids, Chem. Geol., 184, 37-48, 2002.

Draganic, I. G., Bjergbakke, E., Draganic, Z. D., and Sehested, K.: Decomposition of ocean waters by potassium-40 radiation $3800 \mathrm{Ma}$ ago as a source of oxygen and oxidizing species, Precambrian Research, 52, 337-345, 1991.

Drennan, C. L., Heo, J., Sintchak, M. D., Schreiter, E., and Ludden, P. W.: Life on carbon monoxide: X-ray structure of Rhodospirillium rubrum Ni-Fe-S carbon monoxide dehydrogenase, Proceedings of the National Academy of Science, USA, 98, 11973 $11978,2001$.

Dymek, R. F. and Klein, C.: Chemistry, petrology and origin of banded iron-formation lithologies from the $3800 \mathrm{Ma}$ Isua Supracrustal Belt, West Greenland, Precambrian Research, 39, 247-302, 1988.

Eck, R. V. and Dayhoff, M. O.: Evolution of the structure of ferredoxin based on living relics of primitive amino acid sequences, Science, 152, 363-366, 1966.

Elderfield, H. and Schultz, A.: Mid-ocean ridge hydrothermal fluxes and the chemical composition of the ocean, Annual Review of Earth and Planetary Science, 24, 191-224, 1996.

Eschenmoser, A.: Vitamin B12: experiments concerning the origin of its molecular structure, Angewandte Chemie (International edition in English), 27, 5-39, 1988.

Faggerbakke, K. M., Heldal, M., and Norland, S.: Content of car- 
bon, nitrogen, oxygen, sulfur and phosphorous in native aquatic and cultured bacteria, Aquatic Microbial Ecology, 10, 15-27, 1996.

Farquhar, J., Bao, H., and Thiemens, M. H.: Atmospheric influence of Earth's earliest sulfur cycle, Science, 289, 756-758, 2000.

Ferreira, K. N., Iverson, T. M., Maghlaoui, K., Barber, J., and Iwata, S.: Architecture of the photosynthetic oxygen-evolving center, Science, 303, 1831-1838, 2004.

Filtness, M. J., Butler, I. B., and Rickard, D.: The origin of life: the properties of iron sulphide membranes, Applied Earth Science, Transactions Institution Mining Metallurgy, 112B, 171172, 2003.

Fitton, J. G., Mahoney, J. J., Wallace, P. J., and Saunders, A. D.: Origin and Evolution of the Ontong Java Plateau, Geological Society Special Publication, 229, 1-384, 2004.

Foley, S. F., Buhre, S., and Jacob, D. E.: Evolution of the Archaean crust by delamination and shallow subduction, Nature, 421, 249$252,2003$.

Fontecilla-Camps, J. C. and Ragsdale, S. W.: Nickel-iron-sulfur active sites: Hydrogenase and CO dehydrogenase, Adv. Inorg. Chem., 47, 283-333, 1999.

Forsyth, D. and Uyeda, S.: On the relative importance of the driving forces of plate motion, Geophysical Journal Royal Astronomical Society, 43, 163-200, 1975.

Forterre, P.: A hot topic: the origin of hyperthermophiles, Cell, 85, 789-792, 1996.

Francis, D., Luddon, J., Johnstone, R., and Davis, W.: Picrite evidence for more $\mathrm{Fe}$ in Archean mantle reservoirs, Earth Planet. Sc. Lett., 167, 197-213, 1999.

Froude, D. O., Ireland, T. R., Kinny, P. O., Williams I. S., and Compston, W.: Ion microprobe identification of 4100-4200 Myr old terrestrial zircons, Nature, 304, 616-618, 1983.

Früh-Green, G. L., Kelley D. S., Bernasconi, S. M., Karson, J. A., Ludwig, K. A., Butterfield, D. A., Boschi, C., and Proskurowski, G.: 30000 years of hydrothermal activity at the Lost City vent field, Science, 301, 495-498, 2003.

Fyfe, W. S.: Heats of chemical reactions and submarine heat production, Geophysical Journal Royal Astronomical Society, 37, 213-215, 1974.

Furnes, H., Banerjee, N. R., Muehlenbachs, K., Staudigel, H., and de Wit, M.: Early life recorded in Archean pillow lavas, Science, 304, 578-581, 2004.

Gaffey, M. J.: The early solar system, Origins of Life and Evolution of the Biosphere, 27, 185-203, 1997.

Gaucher, E. A., Thomson, J. M., Burgan, M., and Benner, S. A.: Inferring the palaeoenvironment of ancient bacteria on the basis of resurrected proteins, Nature, 425, 285-288, 2003.

Geptner, A., Kristmannsdöttir, H., Kristjánsson, J. K., and Marteinsson, V. Th.: Biogenic saponite from an active submarine hot spring, Iceland, Clays and Clay Minerals, 50, 174-185, 2002

Glikson, A. Y.: Early Precambrian evidence of a primitive oceanic crust and island nuclei of sodic granite, Geological Society of America Bulletin, 83, 3323-3344, 1972.

Haeckel, E.: The History of Creation, volume 1, translated by: Lankester, E. R., fourth edition, Appleton, London, 1892.

Hall, D. O., Cammack, R., and Rao, K. K.: Role for ferredoxins in the origin of life and biological evolution, Nature, 233, 136-138, 1971.
Hansson, Ö., and Wydrzynski, T.: Current perceptions of Photosystem II, Photsyn. Res., 23, 131-162, 1990.

Heinen, W. and Lauwers, A. M.: Organic sulfur compounds resulting from the interaction of iron sulfide, hydrogen sulfide and carbon dioxide in an anaerobic aqueous environment, Origins of Life and Evolution of the Biosphere, 26, 131-150, 1996.

Hennet, R. J.-C., Holm, N. G., and Engel, M. H.: Abiotic synthesis of amino acids under hydrothermal conditions and the origin of life: A perpetual phenomenon?, Naturwissenschaften, 79, 361365, 1992.

Hoehler, T. M., Bebout, B. M., and Des Marais, D. J.: The role of microbial mats in the production of reduced gases on the early Earth, Nature, 412, 324-327, 2001.

Holland, H. D.: Volcanic gases, black smokers, and the Great Oxidation Event, Geochimica et Cosmochimica Acta, 66, 38113826, 2002.

Holmes, A.: Radioactivity and Earth movements, Transactions of the Geological Society of Glasgow, 18, 559-606, 1931.

Huber, C., and Wächtershäuser, G.: Activated acetic acid by carbon fixation on $(\mathrm{Fe}, \mathrm{Ni}) \mathrm{S}$ under primordial conditions, Science, 276, 245-247, 1997.

Huber, C. and Wächtershäuser, G.: Peptides by activation of amino acids on $(\mathrm{Fe}, \mathrm{Ni}) \mathrm{S}$ surfaces: Implications for the origin of life, Science, 281, 670-672, 1998.

Huber, C., and Wächtershäuser, G.: Primordial reductive amination revisited, Tetrahedron Lett., 44, 1695-1697, 2003.

Iizuka, T., Komiya, T., Hirata, T., and Maruyama, S.: Zircon geochronology and geochemistry of the Acasta Gneiss Complex in Slave Province, Northern Canada, AGU Fall Meeting, abstract \#V62A-1384, 2002.

Janecky, D. R. and Seyfried, W. E.: The solubility of magnesiumhydroxide-sulfate-hydrate in seawater at elevated temperatures and pressures, American Journal of Science, 283, 831-860, 1983.

Jacob, D., Jagoutz, E., Lowry, D., Mattey, D., and Kudrjavtseva, G. P.: Diamondiferous eclogites from Siberia: Remnants of Archean oceanic crust, Geochimica et Cosmochimica Acta, 58, 5191-5207, 1994.

Kakegawa, T., Noda, M., and Nannri, H.: Geochemical cycles of bio-essential elements on the early Earth and their relationships to the origin of life, Res. Geol., 52, 83-89, 2002.

Karsten, J. L., Klein, E. M., and Sherman, S. B.: Subduction zone geochemical characteristics in ocean ridge basalts from the southern Chile ridge: implications of modern subduction systems for the Archean, Lithos, 37, 143-161, 1996.

Kasting, J. F.: Earth's early atmosphere, Science, 259, 920-926, 1993.

Kasting, J. F. and Ackerman, T. P.: Climatic consequences of very high carbon dioxide levels in the earth's early atmosphere, Science, 234, 1383-1385, 1986.

Kasting, J. F. and Brown, L. L.: The early atmosphere as a source of biogenic compounds, In The Molecular Origins of Life, A. Brack, editor, Cambridge University Press, 35-56, 1998.

Kelley, D. S., Karson, J. A., Blackman, D. K., Früh-Green, G. L., Butterfield, D. A., Lilley, M. D., Olsen, E. J., Schrenk, M. O., Roe, K. K., Lebon, G. Y., and Rivizzigno, P.: AT3-60 Shipboard Party.: An off-axis hydrothermal vent field near the Mid-Atlantic Ridge at $30^{\circ} \mathrm{N}$, Nature, 412, 145-149, 2001.

Klein, M., Friedrich, M., Roger, A. J., Hugenholtz, P., Fishbain, 
S., Abicht, H., Blackall, L. L., Stahl, D. A., and Wagner, M.: Multiple lateral transfers of dissimilatory sulfite reductase genes between major lineages of sulfate-reducing prokaryotes, J. Bacteriol., 183, 6028-6035, 2001.

Kling, G. W., Tuttle, M. L., and Evans, W. C.: The evolution of thermal structure and water chemistry in Lake Nyos, J. Volcanol. Geotherm. Res., 39, 151-165, 1989.

Koga, Y., Kyuragi, T., Nishihara, M., and Sone, N.: Did archaeal and bacterial cells arise independently from noncellular precursors? A hypothesis stating that the advent of membrane phospholipid with enantiomeric glycerophosphate backbones caused the separation of the two lines of descent, J. Mol. Evol., 46, 54-63, 1998.

Kotelnikova, S. and Pedersen, K.: Evidence for methanogenic Archaea and homoacetogenic Bacteria in deep granitic rock aquifers, FEMS Microbiology Reviews, 20, 339-349, 1997.

Kramers, J. D.: Volatile element abundance patterns and early liquid water ocean on Earth, Precambrian Research, 126, 379-394, 2003.

Lécuyer, C. and Ricard, Y.: Long-term fluxes and budget of ferric iron for the redox states of the Earth's mantle and atmosphere, Earth Planet. Sc. Lett., 165, 197-211, 1999.

Leduc, S.: The Mechanism of Life, Rebman Ltd, London, 1911.

Leman, L., Orgel, L., and Ghadiri, M.R.: Carbonyl sulfidemediated prebiotic formation of peptides, Science, 306, 283286, 2004.

Liu, S. V., Zhou, J., Zhang, C., Cole, D. R., Gajdarziska-Josifovska, M., and Phelps, T. J.: Thermophilic Fe(III)-reducing bacteria from the deep subsurface: the evolutionary implications, Science, 277, 1106-1109, 1997.

Lowell, R. P. and Rona, P. A.: Seafloor hydrothermal systems driven by serpentinization of peridotite, Geophys. Res. Lett., 29, doi:10.1029/2001GLA014411, 2002.

Luther, G. W., Theberge, S. M., and Rickard, D. T.: Evidence for aqueous clusters as intermediates during zinc sulfide formation, Geochimica et Cosmochimica Acta, 63, 3159-3169, 1999.

Macalady, J. and Banfield, J. F.: Molecular geomicrobiology: genes and geochemical cycling, Earth Planet. Sc. Lett., 209, 1-17, 2003.

Macleod, G., McKeown, C., Hall, A. J., and Russell, M. J.: Hydrothermal and oceanic $\mathrm{pH}$ conditions of possible relevance to the origin of life, Origins of Life and Evolution of the Biosphere, 24, 19-41, 1994.

Madigan, M. T., Matinko, J. M., and Parker, J.: Brock: Biology of Microorganisms, New Jersey, Prentice Hall, 2000.

Maher, K. A. and Stevenson, D. J.: Impact frustration of the origin of life, Nature, 331, 612-614, 1988.

Maisonneuve, J.: The composition of the Precambrian ocean waters, Sed. Geol., 31, 1-11, 1982.

Manceau, A., Lanson, B., and Drits, V. A.: Structure of heavy metal sorbed birnesite. Part III: Results from powder and polarized extended X-ray absorption fine structure spectroscopy, Geochimica et Cosmochimica Acta, 66, 2639-2663, 2002.

Maruyama, S.: Pacific-type orogeny revisisted: Miyashiro-type orogeny proposed, The Island Arc., 6, 91-120, 1997.

Marteinsson, V. Th., Kristjánsson, J. K., Kristmannsdóttir, H., Dahlkvist, M., Sæmundsson, K., Hannington, M., Pétursdóttir, S. K., Geptner, A., and Stoffers, P.: Discovery of giant submarine smectite cones on the seafloor in Eyjafjordur, Northern Iceland, and a novel thermal microbial habitat, Appl. Environ. Microb., 67, 827-833, 2001.

Martin, W. and Russell, M. J.: On the origin of cells: An hypothesis for the evolutionary transitions from abiotic geochemistry to chemoautotrophic prokaryotes, and from prokaryotes to nucleated cells, Philosophical Transactions of the Royal Society of London, 358B, 27-85, 2003.

McFadden, B. A. and Shively, J. M.: Bacterial assimilation of carbon dioxide by the Calvin cycle, in Variation in Autotrophic Life, edited by: Shively, J. M. and Barton, L. L., Academic Press, 2550, 1991.

Mckenzie, D.: Speculations on the consequences and causes of plate motions, Geophysical Journal Royal Astronomical Society, $18,1-32,1969$.

McKenzie, D. and Bickle, M. J.: The volume and composition of melt generated by extension of the lithosphere, J. Petrol., 29, 625-679, 1988.

Menon, S. and Ragsdale, S. W.: Unleashing hydrogenase activity in carbon monoxide dehydrogenase/acetyl-CoA synthase and pyruvate:ferredoxin oxidoreductase, Science, 287, 1245-1247, 2000.

Menon, S. and Ragsdale, S. W.: Unleashing hydrogenase activity in pyruvate:ferredoxin oxidoreductase and acetyl-CoA synthase/CO dehydrogenase, Biochemistry, 35, 15 814-15821, 2000.

Michel, H. and Deisenhofer, J.: Relevance of the photosynthetic reaction center from purple bacteria to the structure of photosystem II, Biochemistry, 27, 1-7, 1988.

Milner-White, E. J. and Russell, M. J.: Nests as sites for phosphates and iron-sulfur thiolates in the first membranes: 3 to 6 residue anion-binding motifs, Origins of Life and Evolution of the Biosphere, 35, 19-27, 2005.

Mojzsis, S. J., Harrison, T. M., and Pidgeon, R. T.: Oxygen-isotope evidence from ancient zircons for liquid water at the Earth's surface 4300 Myr ago, Nature, 409, 178-181, 2001.

Morita, R. Y.: Is $\mathrm{H}_{2}$ the universal energy source for long-term survival?, Microbial Ecology, 38, 307-320, 2000.

Morel, F. M. M. and Hudson, R. J. M.: The geobiological cycle of trace elements in aquatic systems: Redfield revisited, in Chemical Processes in Lakes, edited by: Stumm, W., WileyInterscience, New York, 251-281, 1985.

Moulton, V., Gardner, P. P., Pointon, R. F., Creamer, L. K., Jameson, G. B., and Penny, D.: RNA folding argues agains a hot origin of life, J. Mol. Evol., 51, 416-421, 2000.

Mulkidjanian, A. Y. and Junge, W.: On the origin of photosynthesis as inferred from sequence analysis - a primordial UV-protector as common ancestor of reaction centers and antenna proteins, Photosynth. Res., 51, 27-42, 1997.

Neal, C. and Stanger, G.: Hydrogen generation from mantle source rocks in Oman, Earth Planet. Sc. Lett., 66, 315-320, 1983.

Neal, C. and Stanger, G.: Calcium and magnesium hydroxide precipitation from alkaline groundwater in Oman, and their significance to the process of serpentinization, Mineralogical Magazine, 48, 237-241, 1984.

Nisbet, E. G. and Sleep, N. H.: The habitat and nature of early life, Nature, 409, 1083-1091, 2001.

Orr, W.: Sulfur: In Handbook of Geochemistry, Vol. II/2, edited by: Wedepohl, K. H., Berlin, Springer-Verlag, 16-L-5, 1978.

Pace, N. R.: A molecular view of microbial diversity and the biosphere, Science, 276, 734-740, 1997. 
Pace, N. R.: The large scale topology of the tree of life, Abstract, Astrobiology, 2, 484, 2002.

Parkes, R. J., Cragg, B. A., Fry, J. C., Herbert, R. A., and Wimpenny, J. W. T.: Bacterial biomass and activity in deep sediment layers from the Peru margin, Philosophical Transactions of the Royal Society of London, 331A, 139-153, 1990.

Parkes, R. J., Cragg, B. A., Bale, S. J., Getliff, J. M., Goodman, K., Rochelle, P. A., Fry, J. C., Weightman, A. J., and Harvey, S. M.: Deep bacterial biosphere in Pacific Ocean sediments, Nature, 371, 410-413, 1994.

Pavlov, A. A. and Kasting, J. F.: Mass-independent fractionation of sulfur isotopes in Archean sediments: Strong evidence for an anoxic Archean atmosphere, Astrobiology, 2, 27-41, 2002.

Pederson, K.: The deep subterranean biosphere, Earth Science Reviews, 34, 243-260, 1993.

Peloquin, J. M. and Britt, R. D.: EPR/ENDOR characterization of the physical and electronic structure of the OEC Mn Cluster, Biochimica Biophysica Acta, 1507, 96-111, 2001.

Peretó, J. G., Velasco, A. M., Becerra, A., and Lazcano, A.: Comparative biochemistry of $\mathrm{CO}_{2}$ fixation and the evolution of autotrophy, International Microbiology, 2, 3-10, 1999.

Phoenix, V. R., Konhauser, K. O., Adams, D. G., and Bottrell, S. H.: Role of biomineralization as an ultraviolet shield: Implications for Archean life, Geology, 29, 823-826, 2001.

Post, J. E.: Manganese oxide minerals: Crystal structures and economic and environmental significance, Proceedings of the National Academy of Science, USA, 96, 3447-3454, 1999.

Post, J. E. and Veblen, D. R.: Crystal structure determinations of synthetic sodium, magnesium, and potassium birnessite using TEM and the Rietveld method, American Mineralogist, 75, 477489,1990

Pratt, J. M.: Nature's design and use of catalysts based on Co and the macrocyclic corrin ligand: $4 \times 10^{9}$ years of coordination chemistry, Pure Appl. Chem., 65, 1513-1520, 1993.

Rahman, L.: The geochemical modelling of emergent life from submarine hydrothermal environments, Unpublished Ph.D Thesis, University of Glasgow, 2002.

Redfield, A. C., Ketchum, B. H., and Richards, F. A.: The influence of organisms on the composition of seawater, in The Sea, v. 2, edited by: Hill, M. N., Wiley-Interscience, New York, 26-77, 1963.

Reysenbach, A. L. and Lovley, D. R.: Geoglobus ahangari, gen. nov., sp., nov., a novel hyperthermophile capable of oxidizing organic acids and growing autotrophically on hydrogen with $\mathrm{Fe}$ (III) serving as the sole electron acceptor, Int. J. System. Evol. Microb., 52, 719-728, 2002.

Rickard, D., Butler, I. B., and Olroyd, A.: A novel iron sulphide switch and its implications for earth and planetary science, Earth Planet. Sc. Lett., 189, 85-91, 2001.

Rosing, M. T. and Frei, R.: U-rich Archaean sea-floor sediments from Greenland - indications of $>3700$ Ma oxygenic photosynthesis, Earth Planet. Sc. Lett., 217, 237-244, 2003.

Russell, M. J.: On the importance of being alkaline, Science, 302, 580-581, 2003.

Russell, M. J. and Hall, A. J.: The emergence of life from iron monosulphide bubbles at a submarine hydrothermal redox and pH front, J. Geol. Soc. London, 154, 377-402, 1997.

Russell, M. J. and Hall, A. J.: From geochemistry to biochemistry: chemiosmotic coupling and transition element clusters in the onset of life and photosynthesis, The Geochemical News, no. 113/October, 6-12, 2002.

Russell, M. J. and Martin, W.: The rocky roots of the acetyl-CoA pathway, Trends in Biochemical Sciences, 29, 358-363, 2004.

Russell, M. J., Daia, D. E., and Hall, A. J.: The emergence of life from $\mathrm{FeS}$ bubbles at alkaline hot springs in an acid ocean, in Thermophiles: The Keys to Molecular Evolution and the Origin of Life, edited by: Wiegel, J., and Adams, M. W. W., Taylor and Francis, Washington, 77-126, 1998.

Russell, M. J., Hall, A. J., and Mellersh, A. R.: On the dissipation of thermal and chemical energies on the early Earth: The onsets of hydrothermal convection, chemiosmosis, genetically regulated metabolism and oxygenic photosynthesis, in Natural and Laboratory-Simulated Thermal Geochemical Processes, edited by: Ikan, R., Dordrecht, Kluwer Academic Publishers, 325-388, 2003.

Russell, M. J., Hall, A. J., Cairns-Smith, A. G., and Braterman, P. S.: Submarine hot springs and the origin of life, Nature correspondence, 336, 117, 1988.

Russell, M. J., Daniel, R. M., Hall, A. J., and Sherringham, J.: A hydrothermally precipitated catalytic iron sulphide membrane as a first step toward life, J. Mol. Evol., 39, 231-243, 1994.

Russell, M. J., Hall, A. J., Fallick, A. E., and Boyce, A. J.: On Hydrothermal Convection Systems and the Emergence of Life, Economic Geology, 100/3, in press, 2005.

Sagan, C. and Mullen, G.: Earth and Mars: Evolution of atmospheres and surface temperatures, Science, 177, 52-56, 1972.

Sandiford, M. and McLaren, S.: Tectonic feedback and the ordering of heat producing elements within the continental lithosphere, Earth Planet. Sc. Lett., 204, 133-150, 2002.

Sauer, K. and Yachandra, V. K.: The water-oxidation complex in photosynthesis, Biochimica et Biophysica Acta - Bioenergetics, 1655, 140-148, 2004.

Schink, B.: Energetics of syntrophic cooperation in methanogenic degradation, Microbiology and Molecular Biology Reviews, 61, 262-280, 1997.

Schulte, M. D. and Rogers, K. L.: Thiols in hydrothermal solution: Standard partial molar properties and their role in the organic geochemistry of hydrothermal environments, Geochimica et Cosmochimica Acta, 68, 1087-1097, 2004.

Schwartzman, D. W. and Lineweaver, C. H.: The hyperthermophilic origin of life revisited, Biochemical Society Transaction, 32, 168-171, 2004.

Sedwick, P. N., McMurtry, G. M., Hilton, D. R., and Goff, F.: Carbon dioxide and helium in hydrothermal fluids from Lothi Seamount, Hawaii, USA, Temporal variability and implications for the release of mantle volatiles, Geochimica et Cosmochimica Acta, 58, 1219-1227, 1994.

Shen, Y. and Buick, R.: The antiquity of microbial sulfate reduction, Earth-Science Reviews, 64, 243-272, 2004.

Shock, E. L.: Chemical environments of submarine hydrothermal systems, Origins of Life and Evolution of the Biosphere, 22, 67 107, 1992.

Shock, E. L., McCollom, T., and Schulte, M. D.: The emergence of metabolism from within hydrothermal systems, in Thermophiles: The Keys to Molecular Evolution and the Origin of Life, edited by: Wiegel, J. and Adams, M. W. W., Taylor and Francis, Washington, 59-76, 1998.

Sleep, N. H. and Windley, B. F.: Archean plate tectonics: con- 
straints and influences, J. Geol., 90, 363-379, 1982.

Sleep, N. H., Zahnle, K. J., Kasting, J. K., and Morowitz, H. J.: Annihilation of ecosystems by large asteroid impacts on the early Earth, Nature, 342, 139-142, 1989.

Sigurdsson, H., Devine, J. D., Tchoua, F. M., Presser, T. S., Pringle, M. K. W., and Evans, W. C.: Origin of the lethal gas burst from Lake Monoun, Cameroon, J. Volcanol. Geotherm. Res., 31, 116, 1987.

Stevens, W. C. and Kurtz, D. M.: Assembly of $\left[\mathrm{Fe}_{n} \mathrm{~S}_{n}(\mathrm{SPh})_{4}\right]^{2-}$ $(n=2,4)$ and their iron-thiolate precursors in aqueous media, American Chemical Society, 24, 3444-3449, 1985.

Stevenson, R. K., David, J., and Parent, M.: Geochemistry and isotopic evolution (Nd, Hf) of the $3.825 \mathrm{Ga}$ Porpoise Cove Sequence, Northeastern Superior Province, Quebec, GAC-MAC, Vancouver, 2003, Abstract, 344, 2003.

Sunda, W. G., Huntsman, S. A., and Harvey, G. R.: Photoreduction of manganese oxides in seawater and its geochemical and biological implications, Nature, 301, 234-236, 1983.

Thauer, R. K.: Biochemistry of methanogenesis: a tribute to Marjory Stephenson, Microbiology, 144, 2377-2406, 1998.

Thorseth, I. H., Torsvik, T., Furnes, H., and Muehlenbachs, K.: Microbes play an important role in the alteration of oceanic crust, Chem. Geol., 126, 137-146, 1995.

Timmins, G. S., Jackson, S. K., and Swartz, H. M.: The evolution of bioluminescent oxygen consumption as an ancient oxygen detoxification mechanism, J. Molecul. Evol., 52, 321-332, 2001.

Towe, K. M.: Environmental oxygen conditions during the origin and evolution of life, Adv. Sp. Res., 18, 7-15, 1996.

Turcotte D. L.: On the thermal evolution of the Earth, Earth Planet. Sc. Lett. 48, 53-58, 1980.

Ueno, Y., Maruyama, S., Isozaki, Y., and Yurimoto, H.: Early Archean (ca. $3.5 \mathrm{Ga}$ ) microfossils and ${ }^{13} \mathrm{C}$-depleted carbonaceous matter in the North Pole area, Western Australia: Field occurrence and geochemistry, in Geochemistry and the Origin of Life, edited by: Nakashima, S., Marayuma, S., Brack, A. and Windley, B. F., Universal Academy Press Inc., Tokyo, Japan, 203-236, 2001.

Van Hunen J., van den Berg, A. P., and Vlaar, N. J.: On the role of subducting oceanic plateaus in the development of shallow flat subduction, Tectonophysics, 352, 317-334, 2002.

Vargas, M., Kashefi, K., Blunt-Harris, E. L., and Lovley, D. R.: Microbial evidence for Fe(III) reduction on early Earth, Nature, 395, 65-67, 1998.

Vaughan, D. J. and Craig, J. R.: Mineral Chemistry of Natural Sulfides, Cambridge University Press, 1978.

Vermaas, W. F. J.: Evolution of heliobacteria: implications for photosynthetic reaction center complexes, Photosynthesis Research, 41, 285-294, 1994.

Vermaas, W. F. J.: Photosynthetic reaction centers, antenna complexes, chlorophyll-binding proteins, gene duplication and divergence, sequence alignment, Encyclopedia of Life Sciences, Nature Publishing Co., http://eee.els.net, 2003.

Von Damm, K. L.: Sea floor hydrothermal activity: Black smoker chemistry and chimneys, Annual Review of Earth and Planetary Sciences, 18, 173-204, 1990.

Von Damm, K. L.: Chemistry of hydrothermal vent fluids from $9^{\circ}-$ $10^{\circ} \mathrm{N}$, East Pacific Rise: 'Time zero", the immediate post eruptive period, J. Geophys. Res., 105, B5, 11 203-11 222, 2000.
Wächtershäuser, G.: Pyrite formation, the first energy source for life: A hypothesis, Systematic Applied Microbiology, 10, 207210, 1988.

Walker, J. C. G. and Brimblecombe, P.: Iron and sulfur in the prebiological ocean, Precambrian Research, 28, 205-222, 1985.

Wenner, D. B. and Taylor, H. P.: Temperatures of serpentinization of ultramafic rocks based on ${ }^{18} \mathrm{O} /{ }^{16} \mathrm{O}$ fractionation between coexisting serpentine and magnetite, Contributions to Mineralogy and Petrology, 32, 165-185, 1971.

Westall, F, de Witt, M. J., Dann, J., Van der Gaast, S., de Ronde, C., and Gerneke, R.: Early Archean Fossil Bacteria and Biofilms in Hydrothermally Influenced Sediments from the Barberton Greenstone Belt, South Africa, Precambrian Research, 106, 93 116, 2001.

Westall, F. and Gould, S. J.: Les procaryotes et leur évolution dans le contexte géologique, Palevol, 2, 485-501, 2003.

Westall, F.: Early life on earth: the fossil record, In: Astrobiology: future perspectives, edited by: Ehrenfreund, P. et al., Kluwer, Dordrecht, 287-316, 2004.

Wellsbury, P., Goodman, K., Barth, T., Cragg, B. A., Barnes, S. P., and Parkes, R. J.: Deep marine biosphere fuelled by increasing organic matter availability during burial and heating, Nature, 388, 573-576, 1997.

Wheat, C. G., Mottl, M. M., and Rudnicki, M.: Trace element and REE composition of a low-temperature ridge-flank hydrothermal spring, Geochimica et Cosmochimica Acta, 66, 3693-3705, 2002.

Whitehouse, M. J. and Kamber, B. S.: On the abundance of light rare earth elements in terrestrial zircons and its implications for Earth's earliest magmatic differentiation, Earth Planet. Sc. Lett., 204, 333-346, 2002.

Whitman, W. B., Coleman, D. C., and Wiebe, W. J.: Prokaryotes: The unseen majority, Proceedings of the National Academy of Science, USA 95, 6578-6583, 1998.

Wicken, J. S.: Evolution, Information and Thermodynamics: Extending the Darwinian Program, Oxford University Press, New York, 1987.

Wilde, S. A., Valley, J. W., Peck, W. H., and Graham, C. M.: Evidence from detrital zircons for the existence of continental crust and oceans on the Earth 4.4 Gyr ago, Nature, 409, 175-178, 2001.

Williams, R. J. P. and da Silva, F. J. J. R.: The Natural Selection of the Chemical Elements: The Environment and Life's Chemistry, Oxford University Press, Oxford, 1996.

Widdel, F., Schnell, S., Heising, S., Ehrenreich, A., Assmus, B., and Schink, B.: Ferrous iron oxidation by anoxygenic phototrophic bacteria, Nature, 362, 834-836, 1993.

Woese, C. R., Kandler, O., and Wheelis, M. L.: Towards a natural system of organisms: proposal for the domains Archaea, Bacteria, and Eucarya, Proceedings of the National Academy of Science, USA, 87, 4576-4579, 1990.

Wolin, M. J.: Hydrogen transfer in microbial communities, in Microbial Interactions and Communities, edited by: Bull, A. T. and Slater, J. H., Academic Press, London, 323-356, 1982.

Wolthers, M., Van der Gaast, S. J., and Rickard, D.: The structure of disordered mackinawite, American Mineralogist, 88, 20072015, 2003. 